\title{
An attempt to monitor pore pressure changes in a block sample during and after sampling
}

\author{
H. A. AMUNDSEN*, J. JØNLAND†, A. EMDAL† and V. THAKUR†
}

\begin{abstract}
A soil sample goes through stress changes during and after sampling. Sensitive clays are affected by sample disturbance and stress changes have a great effect on the quality. The reduction of in-situ total stresses to zero causes the soil sample to develop a negative pore pressure, which is also referred to as residual effective stresses. In an ideal situation, a block sample shall retain its residual effective stress during sampling and storage, which prevents it from swelling. To study this, an attempt was made to monitor the pore pressure variations inside a block sample of soft, sensitive, low-plasticity clay during and after sampling. The pore pressure was measured continuously during the storage period of 3 days and the results were compared with a similar work. The findings suggest that the residual effective stress in block samples may be reduced in a matter of minutes after sampling. Testing performed on reference samples corroborate these storage effects.
\end{abstract}

KEYWORDS: clays; in situ testing; sampling

Published with permission by the ICE under the CC-BY license http://creativecommons.org/licenses/by/4.0/

\section{INTRODUCTION}

Sampling of sensitive clays is a challenging task as their engineering properties, such as undrained shear strength, stiffness and preconsolidation stress, are easily affected by sample disturbance. Sample disturbance in such materials is primarily caused by

- borehole drilling (e.g. Hvorslev, 1949; Clayton, 1986)

- sampler type (e.g. Berre et al., 1969; Lefebvre \& Poulin, 1979; La Rochelle et al., 1981; Baligh, 1985, Amundsen et al., 2015a)

- sealing, transportation, thermal variations, storage method, trimming and handling during preparation for testing (e.g. Bozozuk, 1971; Arman \& McManis, 1976; La Rochelle et al., 1976, 1986; Atkinson et al., 1992)

- stress relief during and after sampling (e.g. Ladd \& Lambe, 1963; Skempton \& Sowa, 1963; Noorany \& Seed, 1965; Bjerrum, 1973)

- changes in the physicochemical properties (e.g. Torrance, 1976; Lessard \& Mitchell, 1985).

Over the years, significant development has taken place to overcome sample disturbances. Extensive studies have shown that block sampling is among the best methods of collecting high-quality samples of soft clays (e.g. DeGroot et al., 2005; Karlsrud \& Hernandez-Martinez, 2013). Accordingly, it has become more common to use Sherbrooke block sampling (Lefebvre \& Poulin, 1979) in sensitive clays as this method ensures that the soil remains unaffected by shear distortions during sampling (e.g. Lacasse et al., 1985; Tanaka et al., 2001). However, one of the issues that is challenging with block sampling is the stress relief. Despite careful handling

Manuscript received 11 December 2016; first decision 25 February 2017; accepted 1 March 2017.

Published online at www.geotechniqueletters.com on 3 April 2017.

*Department of Civil and Environmental Engineering, NTNU, Trondheim, Norway (Orcid:0000-0001-9618-3443).

$\dagger$ Department of Civil Engineering, NTNU, Trondheim, Norway. and transportation, the clay samples may exhibit poorer quality than anticipated - especially for low-plasticity sensitive clays. The effect of stress relief is exemplified in Fig. 1 using several samples from seven sites in Central Norway. The results indicate a deterioration in the quality of samples with increasing stress relief. Since the development of stress relief over time is of high importance, an attempt has been made to study this by continuous monitoring of the pore pressure inside a sample during the sampling process. Before sampling, a wireless pore pressure sensor was inserted into the ground and left to stabilise. A block sample was taken of the soil containing the piezometer and the pore pressure was recorded throughout the insertion, sampling, handling and storage.

\section{THEORETICAL BACKGROUND FOR PORE PRESSURE VARIATION DURING SAMPLING}

During tube sampling, the soil experiences load changes that follow a compression-extension-compression strain cycle (Baligh et al., 1987). This is eliminated during block sampling. Unfortunately, a block sample experiences the effect of stress relief, which may lead to swelling of the soil structure. After a block sample is taken out of the ground, it develops a negative pore water pressure (Ladd \& Lambe, 1963). This generates a pressure gradient, which transports the pore water from the remoulded and destructured clay on the surface of the sample to the intact clay in the middle (Kallstenius, 1971). This water migration may be accompanied by gas exsolution if the pore water contains dissolved gases (Fredlund et al., 2012). As a result of this, the pore volume is allowed to expand, which leads to a reduction of the residual effective stress (RES or $p_{\mathrm{r}}^{\prime}$ ) and causes the intact soil to swell (e.g. Tanaka \& Tanaka, 2006).

Table 1 presents an overview of the stress changes a saturated block sample experiences, from an initial stress condition before the sampling (a), during sampling $(a-b)$, and after $(\mathrm{b}-\mathrm{c})$. During sampling, a block sample is removed from its in-situ conditions into an isotropic state where it develops a negative pore water pressure. Following 


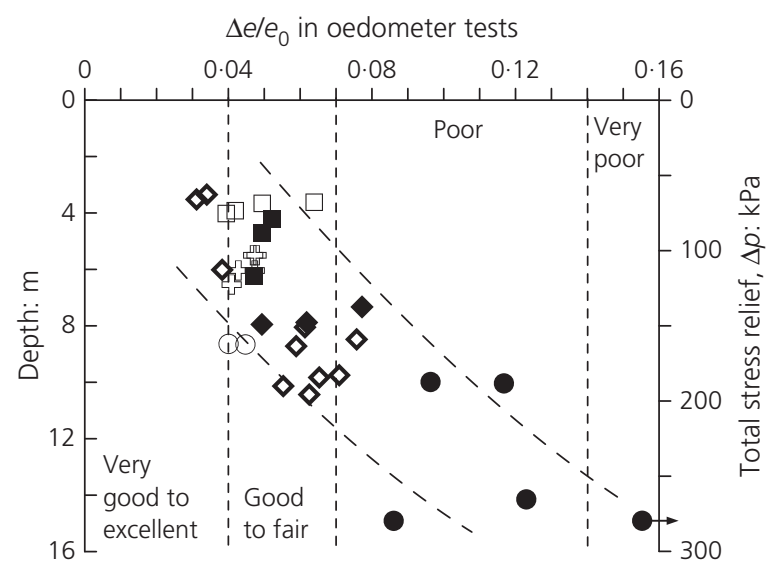

Low plasticity soft clays from Central Norway

$\begin{array}{lrcl} & \begin{array}{r}\text { Overconsolidation } \\ \text { ratio (OCR) }\end{array} & \begin{array}{l}\text { Plasticity } \\ \text { index }\left(I_{p}\right)\end{array} & \begin{array}{l}\text { Sensitivity } \\ \left(S_{t}\right)\end{array} \\ \text { O Møllenberg } & 2 \cdot 3 & 5 \cdot 9 & 400 \\ \text { † Skatval } & 2 \cdot 2-2 \cdot 3 & 8 \cdot 8 & 10 \\ \square \text { Rissa } & 2 \cdot 1-2 \cdot 2 & 8 \cdot 5 & 16 \\ \diamond \text { Tiller } & 1 \cdot 6-2 \cdot 2 & 8 \cdot 7 & 10-240 \\ \text { - Byneset } & 1 \cdot 5-2 \cdot 0 & 6 \cdot 5 & 100 \\ \text { - Dragvoll } & 1 \cdot 4-1 \cdot 9 & 4 \cdot 4 & 100 \\ \text { - Klett } & 1 \cdot 2-1 \cdot 4 & 4 \cdot 0 & 200\end{array}$

Fig. 1. Normalised change in void ratio $\left(\Delta e / e_{0}, e_{0}-\right.$ initial void ratio), which represents the sample quality for OCR 1-2 (Lunne et al., 1997a), against depth and an estimated total stress relief after sampling (for block samples with 160 and $250 \mathrm{~mm}$ in diameter) in Norwegian low-plasticity clays (Helle et al., 2015; Amundsen et al., 2015a, 2015b, 2016a)
Ladd \& Lambe (1963), the pore pressure after the sampling should be

$$
u_{\mathrm{ps}}=-\sigma_{\mathrm{v} 0}^{\prime}\left[K_{0}^{\prime}+A_{\mathrm{u}}\left(1-K_{0}^{\prime}\right)\right]
$$

where $A_{\mathrm{u}}=\left(\Delta u-\Delta \sigma_{\mathrm{h}}\right) /\left(\Delta \sigma_{\mathrm{v}}-\Delta \sigma_{\mathrm{h}}\right)$. Ladd \& Lambe (1963) found $A_{\mathrm{u}}$ for unloading of soil samples to be between $-0 \cdot 1$ and $0 \cdot 3$. However, based on the triaxial tests conducted on the Tiller clay, an elastic response with $A_{\mathrm{u}}=1 / 3$ is assumed

$$
u_{\mathrm{ps}}=-\frac{\sigma_{\mathrm{v} 0}^{\prime}\left(1+2 K_{0}^{\prime}\right)}{3}
$$

Note that $K_{0}^{\prime}$ has a large influence on the theoretical value of $u_{\mathrm{ps}}$. For an isotropic stress state, $u_{\mathrm{ps}}=-\sigma_{\mathrm{v} 0}^{\prime}$, whereas for an anisotropic stress state $\left(K_{0}^{\prime}=0 \cdot 5\right)$ it is equal to $-2 \sigma_{\mathrm{v} 0}^{\prime} / 3$.

The current design of the block sampler does not restrict a sample from swelling during and after sampling, and therefore, the loss of RES will increase with time. However, materials of low overconsolidation ratio $(\mathrm{OCR})$ and $I_{\mathrm{p}}$ may not follow a theoretical path during unloading, $(\mathrm{a}-\mathrm{b})$ as in Table 1, and rather follow the $(\mathrm{a}-\mathrm{d})$ path where $p_{\mathrm{r}}^{\prime}<p_{\mathrm{ps}}^{\prime}$ Similar observations are also reported in the literature (Table 2), where the relation between $I_{\mathrm{p}}$ and the OCR is illustrated (e.g. Gens, 1982; Hight \& Burland, 1990; Carrubba, 2000).

\section{MATERIAL AND METHODOLOGY}

The Norwegian University of Science and Technology (NTNU) has established a geotechnical research site at Tiller, near Trondheim. The characterisation and engineering properties of the clay are well documented in the

Table 1. Sampling-induced stress changes

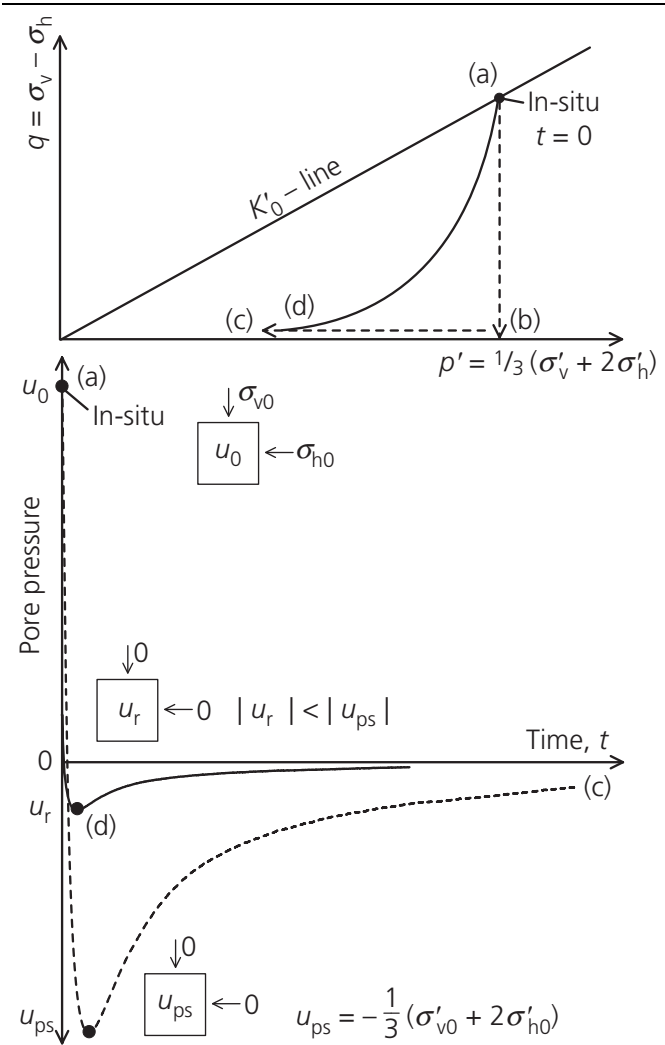

(b) (a) In-situ (before sampling)

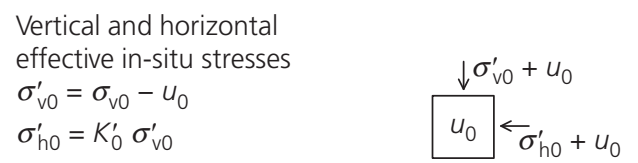

(a)-(b) Sampling, idealised undrained unloading No volumetric change, $\Delta V=0$

Theoretical pore pressure

$$
\begin{aligned}
& \begin{array}{ll}
\downarrow^{0} & \Delta_{u}=\Delta_{p} \\
u_{\mathrm{ps}}=u_{0}+\Delta_{u}
\end{array} \\
& u_{\mathrm{ps}}=u_{0}-\frac{1}{3}\left(\sigma_{\mathrm{v} 0}+2 \sigma_{\mathrm{h} 0}\right) \quad \square \leftarrow p_{\mathrm{ps}}^{\prime} \\
& u_{\mathrm{ps}}=-\frac{1}{3}\left(\sigma_{\mathrm{v} 0}^{\prime}+2 \sigma_{\mathrm{h} 0}^{\prime}\right) \quad p_{\mathrm{ps}}^{\prime}=-u_{\mathrm{ps}}
\end{aligned}
$$

(b)-(c) Idealised behaviour after sampling Swelling due to stress relief, $\Delta V>0$

(a)-(d)-(c) Behaviour of low plasticity clay sand non-plastic materials (real behaviour)

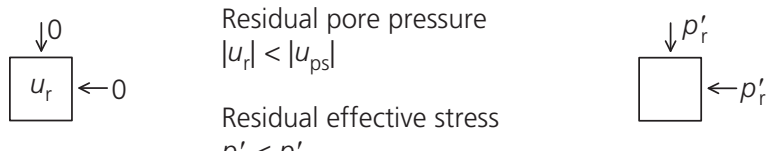

$\sigma_{\mathrm{v} 0}, \sigma_{\mathrm{v} 0}^{\prime}$ are the initial total and effective overburden stress; $u_{0}$ is the initial pore pressure; $\sigma_{\mathrm{h} 0}, \sigma_{\mathrm{h} 0}^{\prime}$ are the initial total and effective horizontal stress; $K_{0}^{\prime}$ is the coefficient of earth pressure at rest; $\Delta V$ is the volumetric change; $p, p^{\prime}$ are the mean total and effective stress; $u_{\mathrm{ps}}, p_{\mathrm{ps}}^{\prime}$ are the pore pressure and mean effective stress after sampling, where ps stands for 'perfect sampling' (see Ladd \& Lambe (1963) for more details); $u_{\mathrm{r}}, p_{\mathrm{r}}^{\prime}$ are the residual pore pressure and RES. Sampling includes the drilling of the borehole, as well as extraction of the sample to the ground surface. 
Table 2. Literature review of some previous studies related to stress relief. $p_{\mathrm{ps}}^{\prime}$ was set to be equal to the mean effective stress, assuming an elastic response during the unloading

\begin{tabular}{|c|c|c|c|c|c|c|c|c|c|c|}
\hline \multirow[t]{2}{*}{ Year } & & \multirow[t]{2}{*}{ Site } & \multicolumn{4}{|c|}{ Material properties } & \multirow{2}{*}{$\begin{array}{l}\text { Method } \\
\text { A-I* }\end{array}$} & \multicolumn{3}{|c|}{ Range of } \\
\hline & & & $S_{\mathrm{t}}$ & $w: \%$ & $I_{\mathrm{p}}: \%$ & OCR & & $p_{\mathrm{r}}^{\prime}: \mathrm{kPa}$ & $p_{\mathrm{r}}^{\prime} / p_{\mathrm{ps}}^{\prime}$ & $p_{\mathrm{r}}^{\prime} / \sigma_{\mathrm{v} 0}^{\prime}$ \\
\hline \multirow[t]{4}{*}{1963} & Slurry & Weald $^{1}$ & 2 & $33-49$ & 24 & $\mathrm{NC}$ & A & $117-676$ & $0 \cdot 78-0 \cdot 80$ & $0.57-0.61$ \\
\hline & Tube & Boston Blue $^{2}$ & & & 14 & $\mathrm{NC}-\mathrm{OC}$ & A & $3-58$ & $0 \cdot 01-0 \cdot 34$ & $0 \cdot 01-0 \cdot 31$ \\
\hline & Tube & Lagunillas $^{2}$ & & $51-60$ & 37 & $\mathrm{NC}$ & A & $12-17$ & $0 \cdot 29-0 \cdot 43$ & $0 \cdot 19-0 \cdot 27$ \\
\hline & abe & Kawasaki ${ }^{2}$ & & $65-68$ & $31-43$ & $\mathrm{NC}$ & A & $17-34$ & $0 \cdot 11-0 \cdot 43$ & $0.08-0 \cdot 24$ \\
\hline \multirow[t]{2}{*}{1971} & Tube & Ellingsrud $^{3}$ & 70 & 40 & 3 & $\mathrm{NC}$ & G & 14 & $0 \cdot 27$ & $0 \cdot 19$ \\
\hline & Block & Lambton $^{4}$ & Low & 31 & 18 & $\mathrm{OC}$ & $\mathrm{F}$ & 75 & $0 \cdot 21$ & $0 \cdot 15$ \\
\hline \multirow[t]{4}{*}{ 1984-1988 } & Slurry & Kaolin $^{5}$ & & $40-46$ & 30 & $\mathrm{NC}$ & A & $54-124$ & $0 \cdot 14-0 \cdot 31$ & $0 \cdot 10-0 \cdot 22$ \\
\hline & Slurry & Illite $^{5}$ & & $34-41$ & 40 & $\mathrm{NC}$ & A & $98-188$ & $0 \cdot 25-0 \cdot 48$ & $0 \cdot 18-0 \cdot 34$ \\
\hline & Slurry & Illite $^{6,7}$ & & $36-43$ & 32 & $\mathrm{NC}$ & A & $57-90$ & $0 \cdot 52-0 \cdot 84$ & $0 \cdot 36-0 \cdot 58$ \\
\hline & Slurry & Illite $^{6,7}$ & & $36-43$ & 32 & $\mathrm{OC}$ & A & $44-52$ & $0 \cdot 80-0 \cdot 95$ & $0.55-0.65$ \\
\hline \multirow[t]{4}{*}{ 1982-1990 } & Slurry & Silt $^{8,9}$ & & & & $\mathrm{NC}$ & A & & & 0.32 \\
\hline & Slurry & Lower Cromer Till & & & 13 & $\mathrm{NC}$ & A & & & $0 \cdot 45$ \\
\hline & Slurry & Magnus $^{8,9}$ & & & 17 & $\mathrm{NC}$ & A & & & $0 \cdot 67$ \\
\hline & Slurry & Florida $^{8,9}$ & & & 163 & $\mathrm{NC}$ & A & & & 0.73 \\
\hline 1992 & Block & Bothkennar $^{10,11}$ & $5-15$ & $51-68$ & $32-45$ & $\mathrm{NC}-\mathrm{OC}$ & A & $10-55$ & $0 \cdot 21-0 \cdot 91$ & $0 \cdot 16-0 \cdot 70$ \\
\hline \multirow{5}{*}{ 1996-2006 } & Block & Bothkennar ${ }^{13,15}$ & $5-15$ & $51-68$ & $32-45$ & $\mathrm{NC}-\mathrm{OC}$ & D & $5-19$ & & $0 \cdot 14-0 \cdot 26$ \\
\hline & Tube & Bothkennar $^{12-15}$ & $5-15$ & $51-68$ & $32-45$ & $\mathrm{NC}-\mathrm{OC}$ & $\mathrm{D}$ & $4-24$ & & $0 \cdot 10-0 \cdot 44$ \\
\hline & Tube & Lierstranda $^{12}$ & $7-15$ & $30-43$ & $16-27$ & $\mathrm{NC}$ & $\mathrm{D}$ & $2-10$ & & $0 \cdot 01-0 \cdot 10$ \\
\hline & Tube & Ishinomaki $^{14,15}$ & & 40 & 25 & $\mathrm{NC}$ & $\mathrm{D}$ & $4-19$ & & $0 \cdot 02-0 \cdot 11$ \\
\hline & Tube & Singapore ${ }^{14,15}$ & & $50-60$ & $42-57$ & $\mathrm{NC}$ & $\mathrm{D}$ & $34-56$ & & $0 \cdot 17-0 \cdot 29$ \\
\hline \multirow[t]{4}{*}{2000} & Slurry & Sandy silt ${ }^{16}$ & & & 6 & $\mathrm{NC}$ & $\mathrm{H}$ & $16-88$ & & $0 \cdot 11-0 \cdot 31$ \\
\hline & Slurry & Clayey silt ${ }^{16}$ & & & 11 & $\mathrm{NC}$ & $\mathrm{H}$ & $16-114$ & & $0 \cdot 14-0 \cdot 31$ \\
\hline & Slurry & Silty clay ${ }^{16}$ & & & 25 & $\mathrm{NC}$ & $\mathrm{H}$ & 30-307 & & $0 \cdot 38-0 \cdot 60$ \\
\hline & Slurry & Organic clay $^{16}$ & & & 75 & $\mathrm{NC}$ & $\mathrm{H}$ & $28-286$ & & $0 \cdot 36-0.57$ \\
\hline 2005 & Block & Boston Blue ${ }^{17}$ & & 45 & 20 & $\mathrm{OC}$ & $\mathrm{E}$ & $13-20$ & $0 \cdot 18-0 \cdot 37$ & $0 \cdot 13-0 \cdot 34$ \\
\hline \multirow[t]{4}{*}{ 2009-2010 } & Block & Onsøy $^{18}$ & $6-8$ & $55-67$ & $25-50$ & $\mathrm{NC}$ & $\mathrm{A}-\mathrm{E}$ & $11-18$ & & $0 \cdot 14-0 \cdot 15$ \\
\hline & Tube & Onsøy $^{18}$ & $6-8$ & $55-67$ & $25-50$ & $\mathrm{NC}$ & A-D & $5 \cdot 6-12$ & & $0 \cdot 07-0 \cdot 15$ \\
\hline & Tube & Ballinasloe $^{18}$ & $3-5$ & $29-42$ & $15-21$ & $\mathrm{NC}$ & A-D & $3 \cdot 2-5 \cdot 2$ & & $0 \cdot 06-0 \cdot 12$ \\
\hline & Tube & Bogganfin $^{19}$ & $1 \cdot 5-3$ & $24-45$ & $12-25$ & $\mathrm{NC}$ & A-D & $3 \cdot 2-4 \cdot 5$ & & $0 \cdot 04-0 \cdot 12$ \\
\hline
\end{tabular}

A-I* (pore pressure measuring methods): A, cell pressure loading; B, filter paper; C, small-scale tensiometer; D, high-air-entry disk; $\mathrm{E}$, suction probe; F, ceramic stone; $\mathrm{G}$, hypodermic needle; $\mathrm{H}$, modified oedometer.

${ }^{1}$ Skempton \& Sowa (1963); ${ }^{2}$ Ladd \& Lambe (1963); ${ }^{3}$ Schjetne (1971); ${ }^{4}$ Adams \& Radhakrishna (1971); ${ }^{5}$ Kirkpatrick \& Khan (1984);

${ }^{6,7}$ Graham et al. (1987), Graham \& Lau (1988); ${ }^{8}$ Gens (1982); ${ }^{9}$ Hight \& Burland (1990); ${ }^{10,11}$ Hight et al. (1992a), Hight et al. (1992b);

${ }^{12-15}$ Tanaka et al. (1996), Tanaka (2000), Tanaka et al. (2001), Tanaka \& Tanaka (2006); ${ }^{16}$ Carrubba (2000); ${ }^{17}$ Poirier et al. (2005);

${ }^{18,19}$ Donohue \& Long (2009), Donohue \& Long (2010).

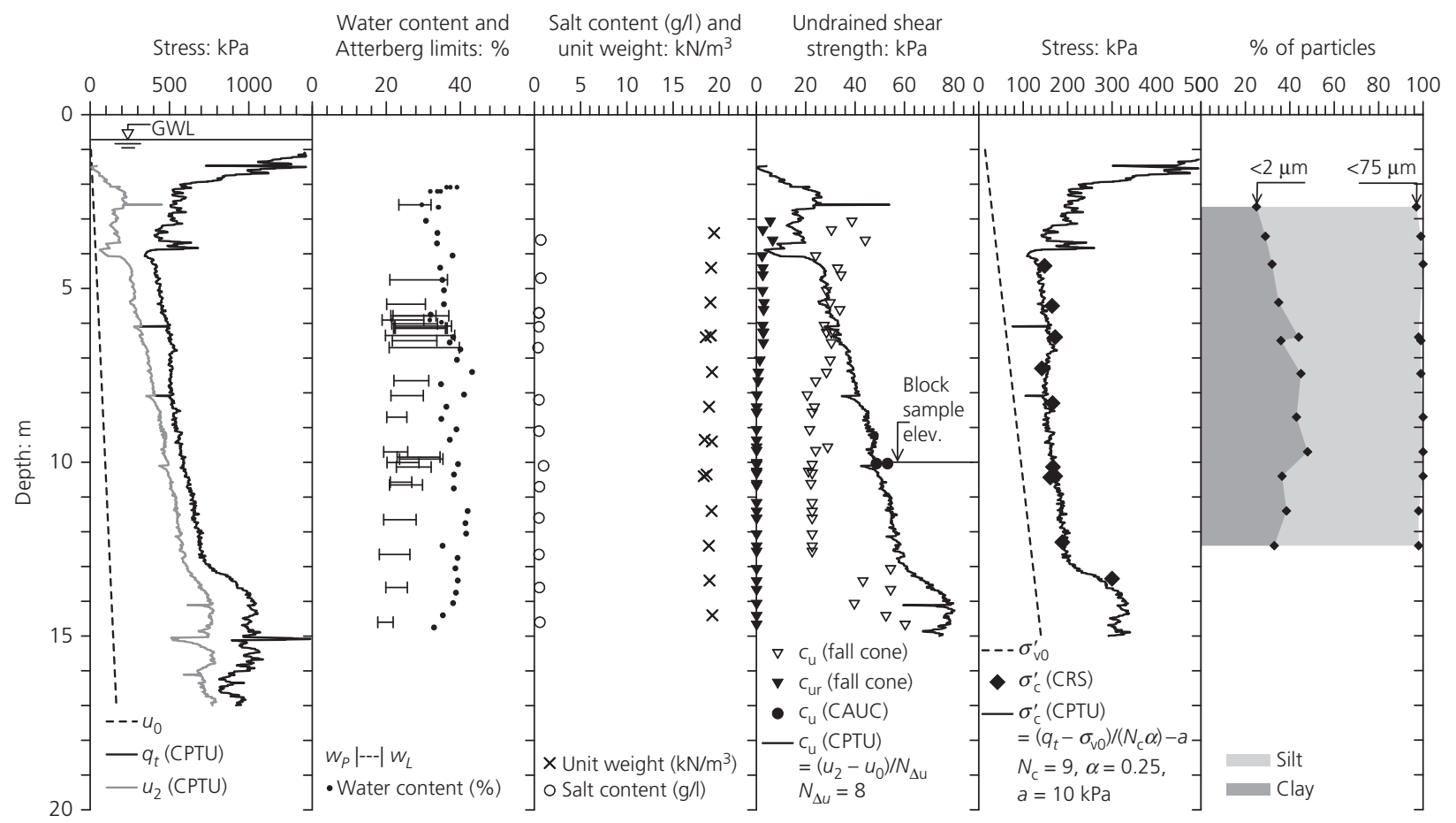

Fig. 2. Geotechnical profile of Tiller site, a leached marine clay deposit. CPTU correlations of the undrained shear strength and preconsolidation stress are based on the work of Lunne et al. (1997b) and Sandven (1990) 


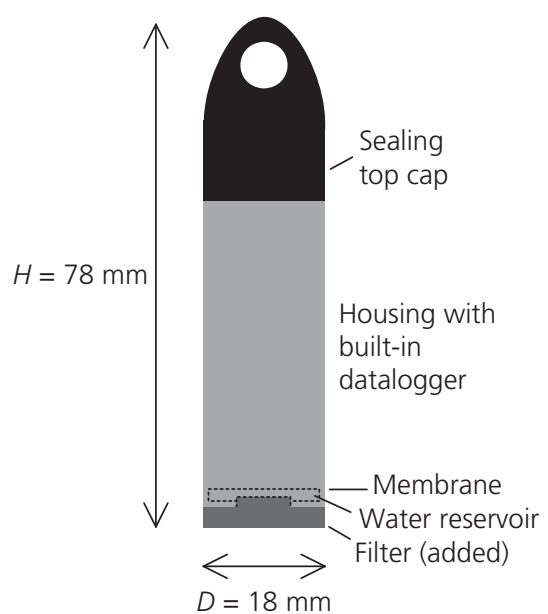

Fig. 3. Modified Micro-Diver piezometer. The pressure sensor has a range, $-65-200 \mathrm{kPa}$

literature (e.g. Sandven et al., 2004; Gylland et al., 2013; Amundsen et al., 2016b) and the geotechnical profile is shown in Fig. 2.

The pore pressure measuring equipment was modified from a commercially produced wireless Micro-Diver datalogger (vanEssen Instruments), shown in Fig. 3. The Micro-Diver consists of a pressure sensor, memory for storing measurements and a battery. The frequency of the measurements is adjustable; in this study, it was set to one measurement every $15 \mathrm{~s}$. The measurements may be downloaded to a computer after the testing is completed. A porous stone filter has been added to protect the membrane and pressure sensor from the soil particles. Before testing, the piezometer calibration was checked using a vacuum pump and a triaxial cell. The water reservoir and the filter were saturated with glycerine prior to installation.

The samples in this study were taken by a downsized version of the Sherbrooke block sampler $(160 \mathrm{~mm}$ in diameter and $300 \mathrm{~mm}$ in height), also called the mini-block sampler, made at NTNU (Emdal et al., 2016).

The installation procedure of the piezometer in the clay is shown in Figs 4(a)-4(c). A hollow steel rod with the piezometer inside was pushed into the ground and the piezometer was released in the undisturbed clay at $10 \mathrm{~m}$. The piezometer was left in the ground (Fig. 4(c)) to stabilise the pore pressure from the installation process. The piezometer was not attached to a cable. Thereafter, the piezometer was retrieved from the ground by overcoring with a mini-block sampler and then sealed immediately (Figs 4(d)-4(f)). The block sample BL0, in Fig. 4(f), contained the piezometer, and only routine tests have been done to compare the material to the reference block samples.

The reference block samples were extracted from a parallel borehole, about $3 \mathrm{~m}$ away, BL1 and BL2 in Fig. 4(f). The samples were sealed and immediately transported to the same laboratory where they were tested. BL1 $(9 \cdot 95-10 \cdot 25 \mathrm{~m})$ was tested in the laboratory $2 \mathrm{~h}$ after the sampling and BL2 $(10 \cdot 25-10.55 \mathrm{~m})$ was stored for $48 \mathrm{~h}$ prior to testing in the same laboratory.

For comparison, constant rate of strain (CRS) oedometer tests and anisotropically consolidated undrained triaxial compression (CAUC) tests were conducted on two reference block samples. The testing equipment, procedures and operator were the same for all tests. The block samples were sliced in an equal manner, as shown by Amundsen et al. (2016b), and the location of the oedometer and triaxial test specimens within the block was the same, close to the undisturbed centre of the block. The specimens were tested immediately after trimming. In general, human errors were minimised and the tested specimens were practically identical.

\section{RESULTS AND DISCUSSION}

Figure 5 shows the measured pore pressure during insertion of the piezometer and sample extraction, which is illustrated in Fig. 4. The drilling started $33 \mathrm{~h}$ after the installation, marked as (3) in Fig. 5, where the upper $5 \mathrm{~m}$ of the soil has been removed and water added to the borehole. This is an established procedure to prepare the borehole prior to block sampling in Norway (Karlsrud et al., 2013). Point (4) in Fig. 5 represents remoulding (by the auger) of the sensitive clay at a depth of 7-9 m, during which the pore pressure varied between 48 and $130 \mathrm{kPa}$. Afterwards, the borehole was filled with water to the ground surface, denoted as (5) in Fig. 5. The carving of two dummy block samples to approach the last section above the piezometer started from point (6) in Fig. 5. This has been registered as an increase in pore pressure, which reduces back to $u_{0}$. The cutting of block sample BL0, the sample with the piezometer, started from point (7) in Fig. 5.

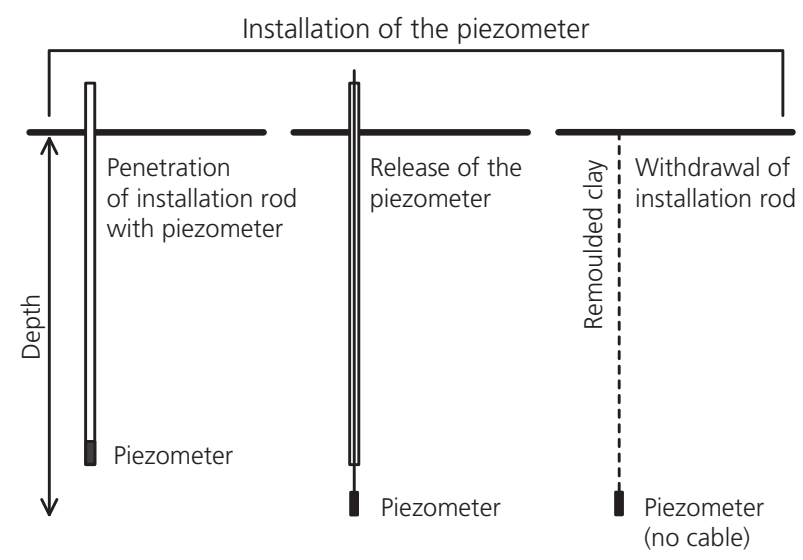

(a) (b)

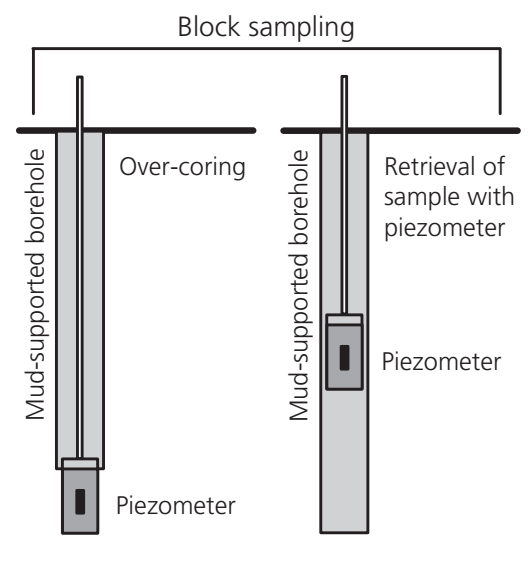

(d)

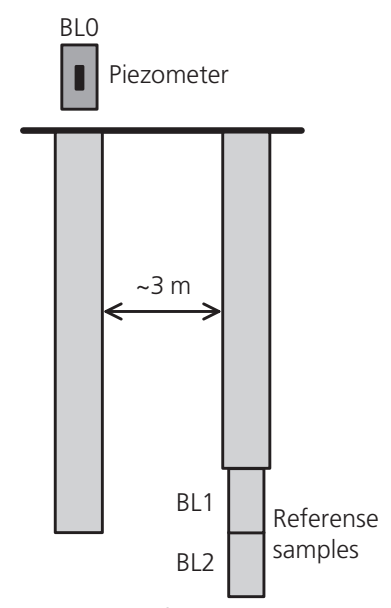

(f)

Fig. 4. (a)-(c) Installation of the piezometer, (d)-(e) overcoring procedure with a block sampler used to retrieve the piezometer inside a block sample and (f) location of the reference block samples 


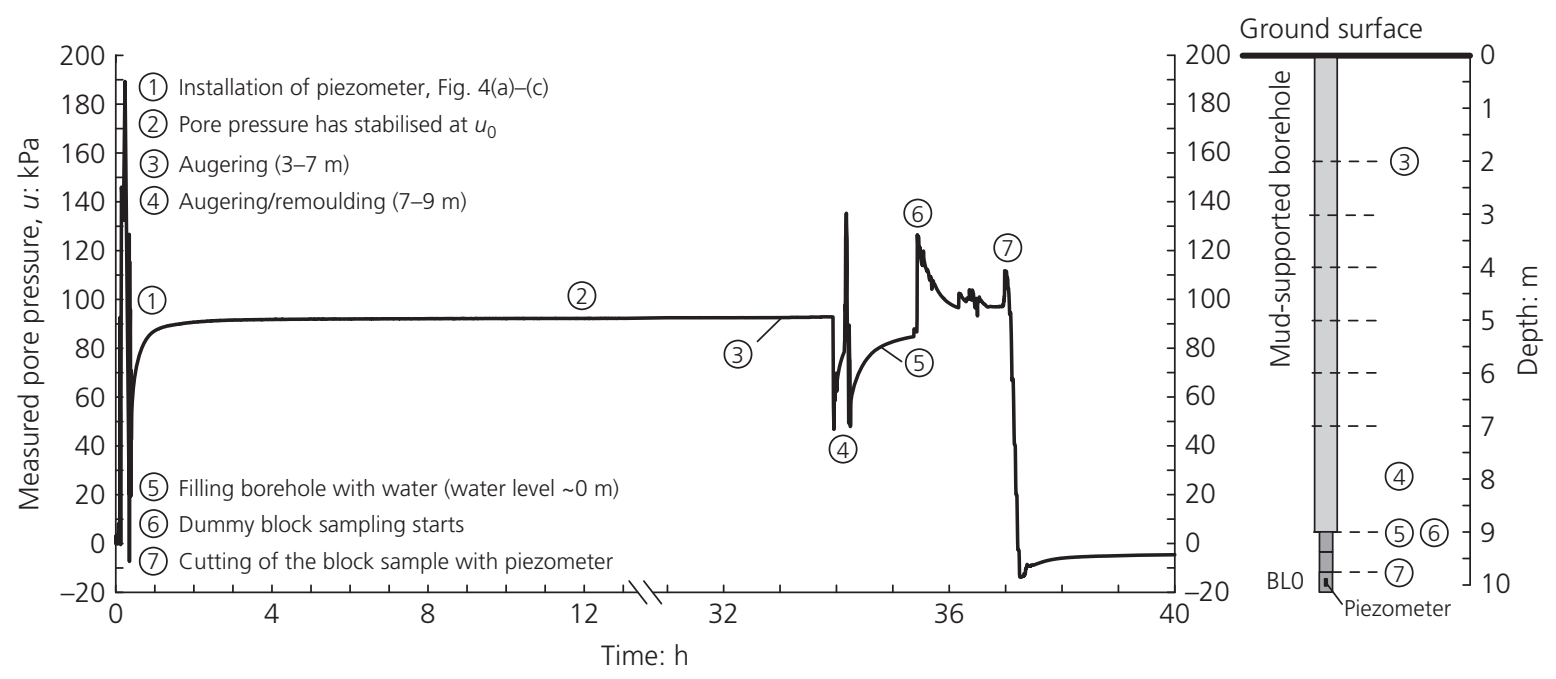

Fig. 5. Pore pressure measured with the piezometer inside a block sample, from the installation until the sampling and storage

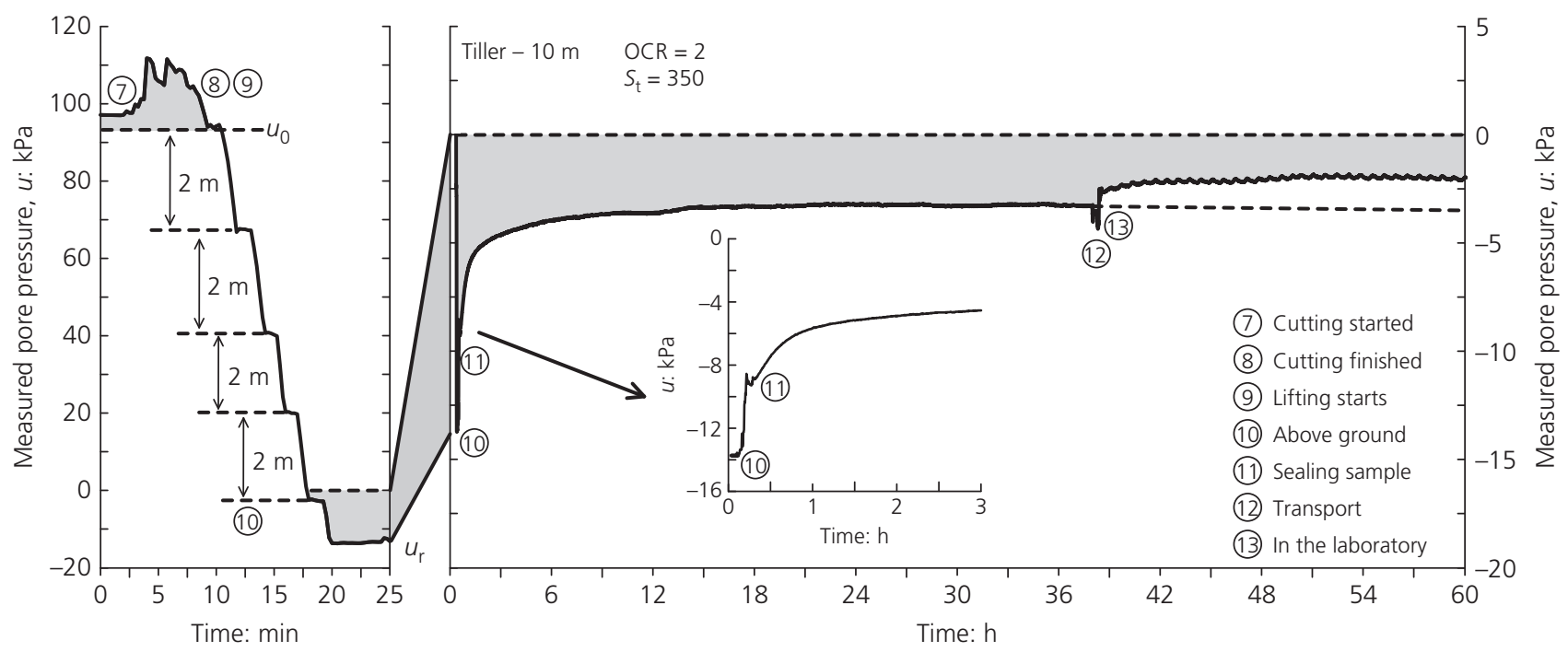

(a)

(b)

Fig. 6. Pore pressure measured with a wireless piezometer inside a block sample during (a) sampling at $10 \mathrm{~m}$, (b) sealing, storage and transport of the sample. It is emphasised that the pore pressure just before the cutting is larger than $u_{0}$ due to the drilling activity

The variations in the measured pore pressure in Fig. 5 indicate that the total vertical stress in the BL0 sample was not constant during drilling. Due to the complexity of the stress condition, this has not been fully addressed in this paper.

In Fig. 6, a more detailed description of the sampling process and the time after is shown, which corresponds to (7) in Fig. 5. The sample was cut during an 8 min period, (7)-(8) in Fig. 6(a), and lifting followed immediately (9)-(10). During this process, several steel rods were detached from the drilling equipment. This was captured by the piezometer (Fig. 6(a)) as short time delays before the lifting continued. A small pore pressure dissipation of $0 \cdot 4-0 \cdot 8 \mathrm{kPa}$ occurred during these time delays. In total, the cutting and lifting of the block sample took about $17 \mathrm{~min}$. Figure 7(a) shows the mini-block sample right after the sampling, with cutting debris covering parts of it. Figure 7(b) shows the sample after the sealing.

Figure 6(b) illustrates the dissipation of the residual pore pressure after sampling (10) and sealing (11), and during the
$38 \mathrm{~h}$ storage before it was transported $12 \mathrm{~km}(12)-(13)$ to the laboratory where it was opened (Fig. 7(c)).

An initial stress condition is presented in Fig. 8(a). Figure 8(b) shows the pore pressure measurements inside the block sample during sampling and lifting of the block in the borehole. During the carving of the block, the total stress changes from $p_{0}$ to $p_{\text {mud }}$. After sampling and during lifting, the sample is submerged in drilling mud, which gives a total isotropic stress ( $\left.p_{\text {mud }}\right)$ on the sample. The difference between the stress from the mud and the measured pore pressure inside the block is the RES in the centre of the sample.

The lowest value of residual pore pressure observed in the block sample was $-13.7 \mathrm{kPa}$ during the first 10 min after sampling. From this point onwards, the sample started to lose its residual pore pressure and within $6 \mathrm{~h}$ after sampling it was $-4 \mathrm{kPa}$.

Results from two oedometer and two triaxial tests from the reference block samples are presented in Fig. 9, along with an interpretation in Table 3. The oedometer tests in Fig. 9(a) show that the sample which was tested after $48 \mathrm{~h}$ of 


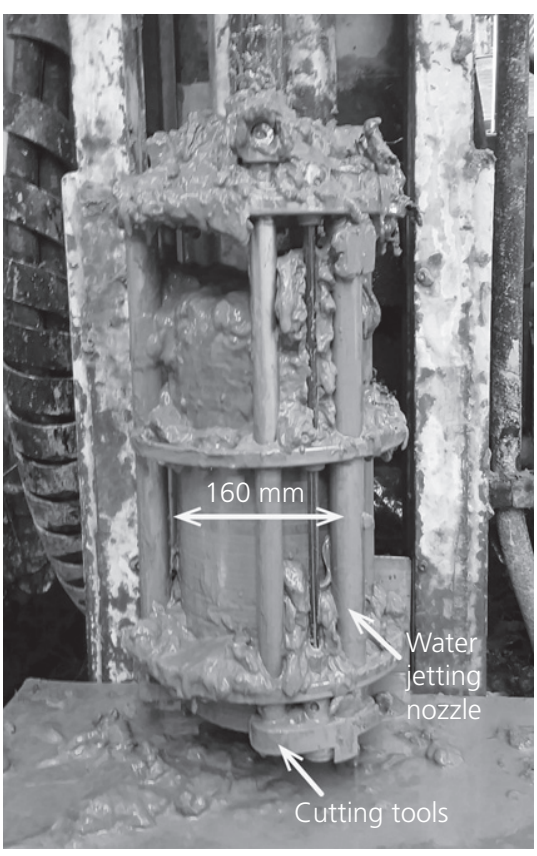

(a)

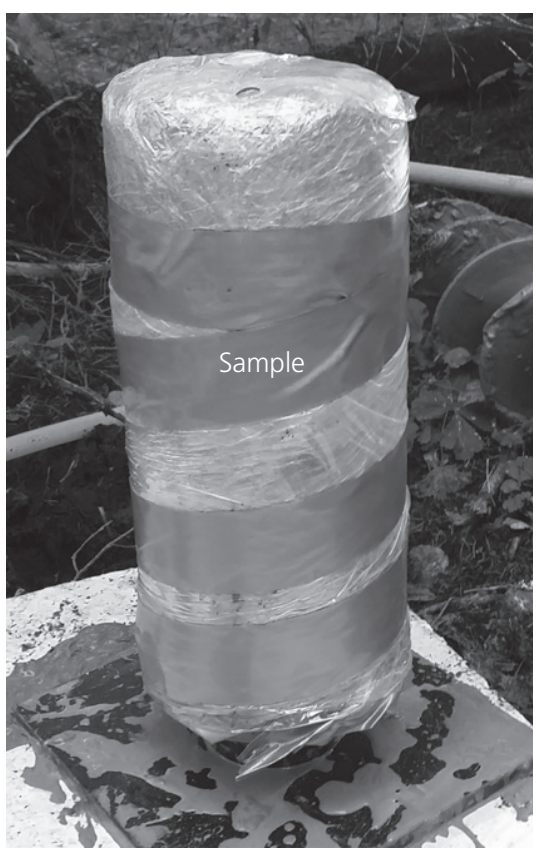

(b)

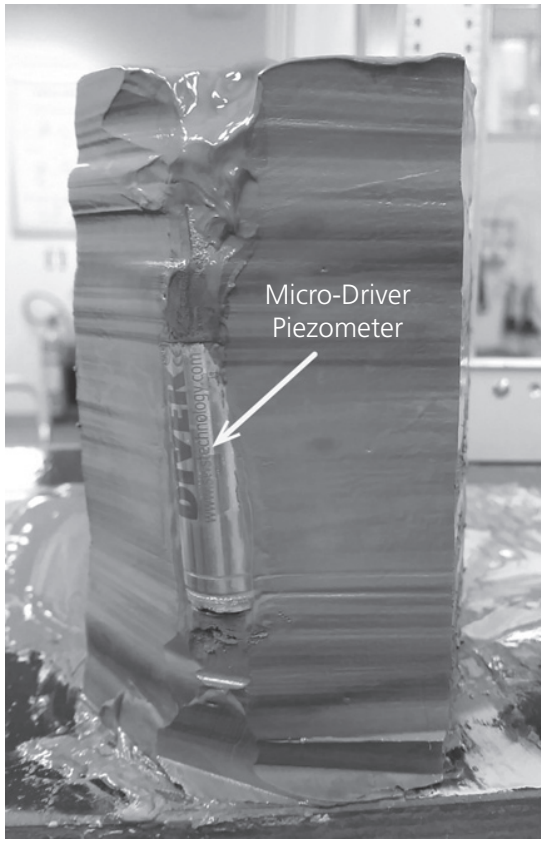

(c)

Fig. 7. The mini-block sample: (a) right after sampling, (b) after sealing and (c) the piezometer inside the block sample

In-situ condition

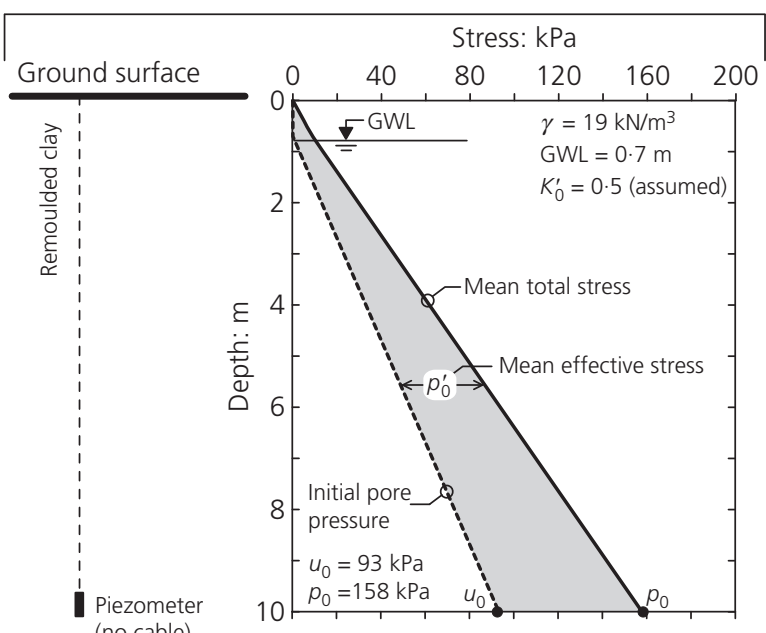

(a)

Stresses inside the block sample (BLO) during lifting

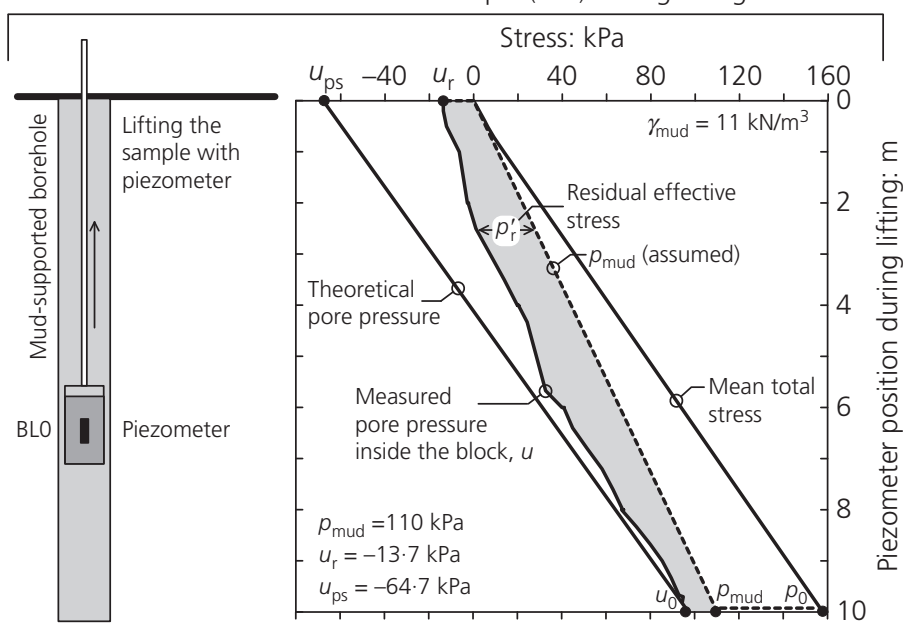

(b)

Fig. 8. (a) In-situ stresses in Tiller clay deposit before drilling, (b) pore pressure measured with a wireless piezometer inside a block sample during extraction of the sample and lifting from $10 \mathrm{~m}$

storage (CRS-2) had about 4\% lower preconsolidation stress and 20\% lower stiffness than the sample tested $2 \mathrm{~h}$ after sampling (CRS-1). The normalised undrained shear strength in the triaxial test CAUC- 2 decreased by $5 \%$, the strain at failure remained unchanged and the pore pressure increased slightly. These results indicate that the material parameter values tend to decrease slightly during the storage period. According to the literature (Ladd \& Lambe, 1963; Hight \& Leroueil, 2003), this cannot be explained by the decrease of the RES. Other reasons such as inhomogeneity of the material, variations during the sampling process, the sealing technique and transport could have caused or attributed to the discrepancies in the measured values. The more realistic in-situ response that has been observed in the samples with little storage time underlines the benefit of beginning testing as soon as possible after sampling. In this case, even sooner than $2 \mathrm{~h}$ after sampling would have been preferred. However, due to the limitations of this study more investigations are needed before conclusions can be drawn.

The theoretical value of the RES after the unloading of the sensitive Tiller clay is $p_{\mathrm{ps}}^{\prime}=-u_{\mathrm{ps}}=65 \mathrm{kPa}$, with an assumed $K_{0}^{\prime}=0.5$ (based on Brooker \& Ireland, 1965; Gylland et al., 2013). The observed maximum RES $\left(p_{\mathrm{r}}^{\prime}=13.7 \mathrm{kPa}\right.$ when the sample is above ground) is very low compared with a theoretical value of $65 \mathrm{kPa}$ and $p_{\mathrm{r}}^{\prime} / p_{\mathrm{ps}}^{\prime}=0 \cdot 21$ and $p_{\mathrm{r}}^{\prime} / \sigma_{\mathrm{v} 0}^{\prime}=0 \cdot 14$. The fact that the negative pore pressure generation was quickly dissipated confirms that the sample does not develop a high RES due to swelling and water migration during the unloading in the borehole. 


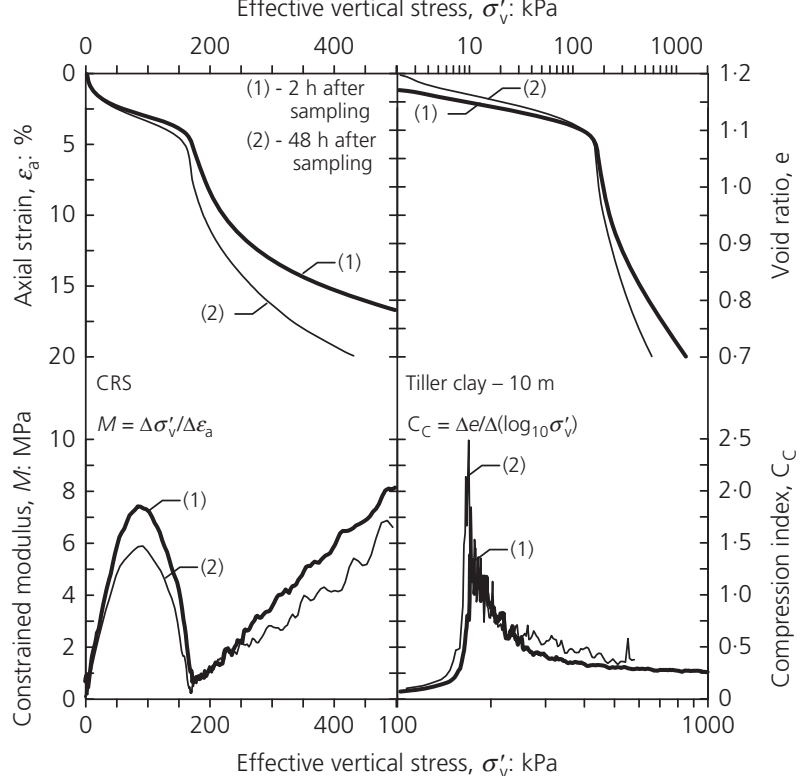

(a)

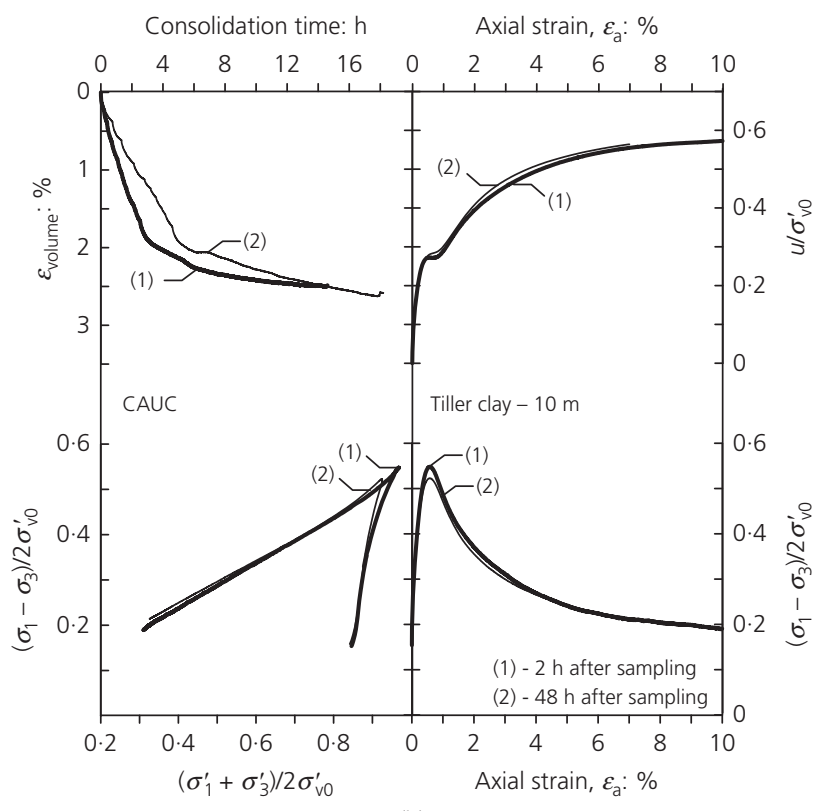

(b)

Fig. 9. Laboratory test results from two (a) oedometer and (b) triaxial tests on block samples on Tiller from $10 \mathrm{~m}$. Tests (1) were conducted $2 \mathrm{~h}$ after sampling and tests (2) $48 \mathrm{~h}$. The consolidation stresses in the triaxial tests were based on an estimation of the in-situ vertical and horizontal effective stresses, $\sigma_{1}^{\prime}$ is the axial consolidation stress and $\sigma_{3}^{\prime}$ is the radial consolidation stress

Table 3. Results from CRS oedometer tests and CAUC triaxial tests on marine sensitive low-plasticity clay from Tiller site

\begin{tabular}{|c|c|c|c|c|c|}
\hline Block sample (BL) & BL0 & BL1 & BL2 & BL1 & BL2 \\
\hline Tests & Piezometer & CRS-1 & CRS-2 & CAUC-1 & CAUC-2 \\
\hline Sample height: mm & 300 & 20 & 20 & 100 & 100 \\
\hline Sample cross-sectional area: $\mathrm{cm}^{2}$ & 201 & 20 & 20 & $22 \cdot 9$ & $22 \cdot 9$ \\
\hline Depth: m & $10 \cdot 0$ & $10 \cdot 1$ & $10 \cdot 4$ & $10 \cdot 0$ & $10 \cdot 3$ \\
\hline Storage time: $\mathrm{h}$ & & 2 & 48 & 2 & 48 \\
\hline Natural water content, $w: \%$ & $40 \cdot 8$ & $41 \cdot 9$ & $42 \cdot 4$ & $40 \cdot 0$ & $42 \cdot 5$ \\
\hline Sensitivity (Swedish fall-cone), $S_{\mathrm{t}}$ & 270 & 270 & 280 & 270 & 280 \\
\hline Liquid limit, $w_{\mathrm{L}}: \%$ & $29 \cdot 6$ & $32 \cdot 1$ & $31 \cdot 2$ & $29 \cdot 7$ & $31 \cdot 1$ \\
\hline Plastic limit, $w_{\mathrm{p}}: \%$ & $20 \cdot 3$ & $22 \cdot 7$ & $21 \cdot 3$ & $20 \cdot 7$ & $21 \cdot 3$ \\
\hline Plasticity index, $I_{\mathrm{p}}: \%$ & $9 \cdot 3$ & $9 \cdot 4$ & $9 \cdot 9$ & $9 \cdot 0$ & $9 \cdot 9$ \\
\hline Liquidity index, $I_{\mathrm{L}}$ & $2 \cdot 2$ & $2 \cdot 0$ & $2 \cdot 1$ & $2 \cdot 1$ & $2 \cdot 1$ \\
\hline In-situ effective vertical stress, $\sigma_{\mathrm{v} 0}^{\prime}: \mathrm{kPa}$ & 97 & 98 & 101 & 97 & 100 \\
\hline In-situ pore pressure, $u_{0}: \mathrm{kPa}, \mathrm{GWL}=0.7 \mathrm{~m}$ & 93 & 94 & 97 & 93 & 96 \\
\hline Strain rate: $\% / \mathrm{h}$ & - & $1 \cdot 0$ & $1 \cdot 0$ & $1 \cdot 5$ & $1 \cdot 5$ \\
\hline \multicolumn{6}{|l|}{ Interpretation of piezometer results } \\
\hline RES after sampling, $p_{\mathrm{r}}^{\prime}: \mathrm{kPa}$ & $13 \cdot 7$ & - & - & - & - \\
\hline$p_{\mathrm{ps}}^{\prime}=-1 / 3\left(1+2 K_{0}^{\prime}\right) \sigma_{\mathrm{v} 0}^{\prime}, K_{0}^{\prime}=0 \cdot 5$ & $64 \cdot 7$ & - & - & - & - \\
\hline$p_{\mathrm{r}}^{\prime} / p_{\mathrm{ps}}^{\prime}$ & $0 \cdot 21$ & - & - & - & - \\
\hline \multicolumn{6}{|l|}{ CRS test interpretation } \\
\hline Preconsolidation pressure, $\sigma_{\mathrm{c}}^{\prime}: \mathrm{kPa}$ & - & 167 & 161 & - & - \\
\hline OCR & - & $1 \cdot 7$ & $1 \cdot 6$ & - & - \\
\hline \multicolumn{6}{|l|}{ CAUC test interpretation } \\
\hline Friction angle, $\phi$ : deg & - & - & - & 30 & 29 \\
\hline Dilatancy parameter, $D=\Delta p^{\prime} / \Delta q$ & - & - & - & $-0 \cdot 02$ & $-0 \cdot 06$ \\
\hline Normalised undrained shear strength, $c_{\mathrm{u}} / \sigma_{\mathrm{v} 0}^{\prime}$ & - & - & - & $0 \cdot 55$ & $0 \cdot 52$ \\
\hline Axial strain at failure, $\varepsilon_{\mathrm{f}}: \%$ & - & - & - & $0 \cdot 58$ & $0 \cdot 58$ \\
\hline Normalised pore pressure at failure, $u_{\mathrm{f}} / \sigma_{\mathrm{v} 0}^{\prime}$ & - & - & - & $0 \cdot 27$ & $0 \cdot 28$ \\
\hline \multicolumn{6}{|l|}{ Sample quality assessment } \\
\hline Volumetric strain at $\varepsilon_{\mathrm{v} 0}$ at $\sigma_{\mathrm{v} 0}^{\prime}: \%$ & - & $3 \cdot 0$ & $3 \cdot 4$ & $2 \cdot 5$ & $2 \cdot 6$ \\
\hline Normalised void ratio, $\Delta e / e_{0}$, at $\sigma_{\mathrm{v} 0}^{\prime}$ & - & $0 \cdot 055$ & 0.063 & $0 \cdot 047$ & $0 \cdot 048$ \\
\hline
\end{tabular}

A rough estimation of the time $(t)$ it would take for the clay to dissipate the RES has been calculated as follows

$$
t=\frac{T_{\mathrm{v}} H^{2}}{c_{\mathrm{h}}}=\frac{R^{2}}{5 c_{\mathrm{v}}}
$$

where $T_{\mathrm{v}}$ is the time factor (assumed $T_{\mathrm{v}}=1$ ); $c_{\mathrm{h}}$ is the coefficient of horizontal consolidation; $c_{\mathrm{v}}$ is the coefficient of vertical consolidation (assumed $c_{\mathrm{h}}=5 c_{\mathrm{v}}$ ) and $H$ is the drainage length, which is equal to the radius of the block sample $(R=8 \mathrm{~cm})$ (Terzaghi et al., 1996). An average $c_{\mathrm{v}}$ for 


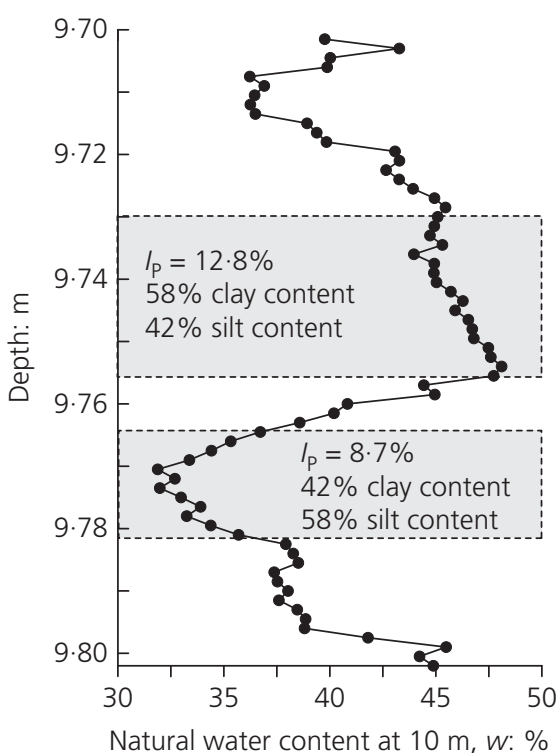

Fig. 10. Variation of water content, plasticity index, clay and silt content in a part of a block sample from Tiller clay, 9.7-9.8 m

the sensitive Tiller clay is $30 \mathrm{~m}^{2} /$ year. The dissipation time is about $20 \mathrm{~min}$. The piezometer measurements agree with the estimation. Other sources such as inhomogeneity, low plasticity and high permeability of the Tiller clay could have attributed to a low RES to some degree. However, no pure silt layers have been observed near the piezometer and the soil was a clay with varying plasticities, similar to Fig. 10.

Schjetne (1971) conducted an in-situ test on sensitive clay of low plasticity, $I_{\mathrm{p}}=3 \%$. He measured the pore pressure during and after sampling with a hypodermic needle in a $95 \mathrm{~mm}$ tube sampler. The results are compared with the measurements in a block sample in Fig. 11. The results show that the tube sample goes through a compression-extensioncompression strain cycle, (1)-(3) in Fig. 11, which may have resulted in an excess pore pressure five times that of the initial. However, the pore pressure variation in the block sample was insignificant during the same process. Also, during the drilling of the borehole (Fig. 5), the pore pressure variations were minor. This confirms that block sampling is a much gentler technique compared with tube sampling. The final ratio of the $p_{\mathrm{r}}^{\prime} / p_{\mathrm{ps}}^{\prime}$ values were $0 \cdot 27$ for the tube sampler and $0 \cdot 21$ for the block sampler, (4) in Fig. 11.

Table 2 is a compilation of results for other materials from the literature, which is compared with the Tiller clay RES. Varieties of natural materials, collected using tube and block samplers, as well as reconstituted samples are included. It is clear that $p_{\mathrm{r}}^{\prime} / p_{\mathrm{ps}}^{\prime}$ and $p_{\mathrm{r}}^{\prime} / \sigma_{\mathrm{v} 0}^{\prime}$ are much lower than the theoretical values of 1.0 and $0 \cdot 67-1 \cdot 0$, assuming an elastic response. A high-plasticity Onsøy clay was able to maintain its RES $(6-15 \mathrm{kPa})$ for at least 3 months, where the $p_{\mathrm{r}}^{\prime} / \sigma_{\mathrm{v} 0}^{\prime}$ ratio varied between $0 \cdot 07$ and $0 \cdot 15$. Other examples are the two medium plasticity clays, Lierstranda and Ishinomaki, which exhibit a $p_{\mathrm{r}}^{\prime} / \sigma_{\mathrm{v} 0}^{\prime}$ ratio of $0 \cdot 01-0 \cdot 11$. There are, however, very few data on natural low-plasticity clays, with an in-situ measurement performed by Schjetne (1971) being, to the best of the authors' knowledge, the only test conducted on such a material. These observations, including other data from natural clays and the conducted in-situ measurements in this study agree. The reconstituted clays are seen to generate a higher $p_{\mathrm{r}}^{\prime} / \sigma_{\mathrm{v} 0}^{\prime}$ ratio compared with natural clays.

There are several limitations to this study. First of all, there was only a single in-situ test conducted, and only two reference samples were sampled and stored. Furthermore, only a limited number of CRS and CAUC tests has been conducted. To strengthen the findings reported herein, more tests are required. Another challenge is the inhomogeneity of the sensitive clay deposit, meaning that the material parameters vary slightly in the sample, as shown in Fig. 10. Finally, the volumetric change of the block sample during sampling, storage and test set-up was not measured and is therefore unknown. Work is currently ongoing in reducing these limitations.

\section{CONCLUDING REMARKS}

This study was conducted to monitor the pore pressure variations during and after sampling in a low-plasticity sensitive clay. It was observed that the sample developed less RES compared with theoretical values. Laboratory testing on the reference samples indicated that the quality of the sample tends to deteriorate with increasing storage time.

The pore pressure response was compared with a field test conducted by Schjetne (1971) on low-plasticity clay. Despite the complete loss of RES, the block sample results indicate

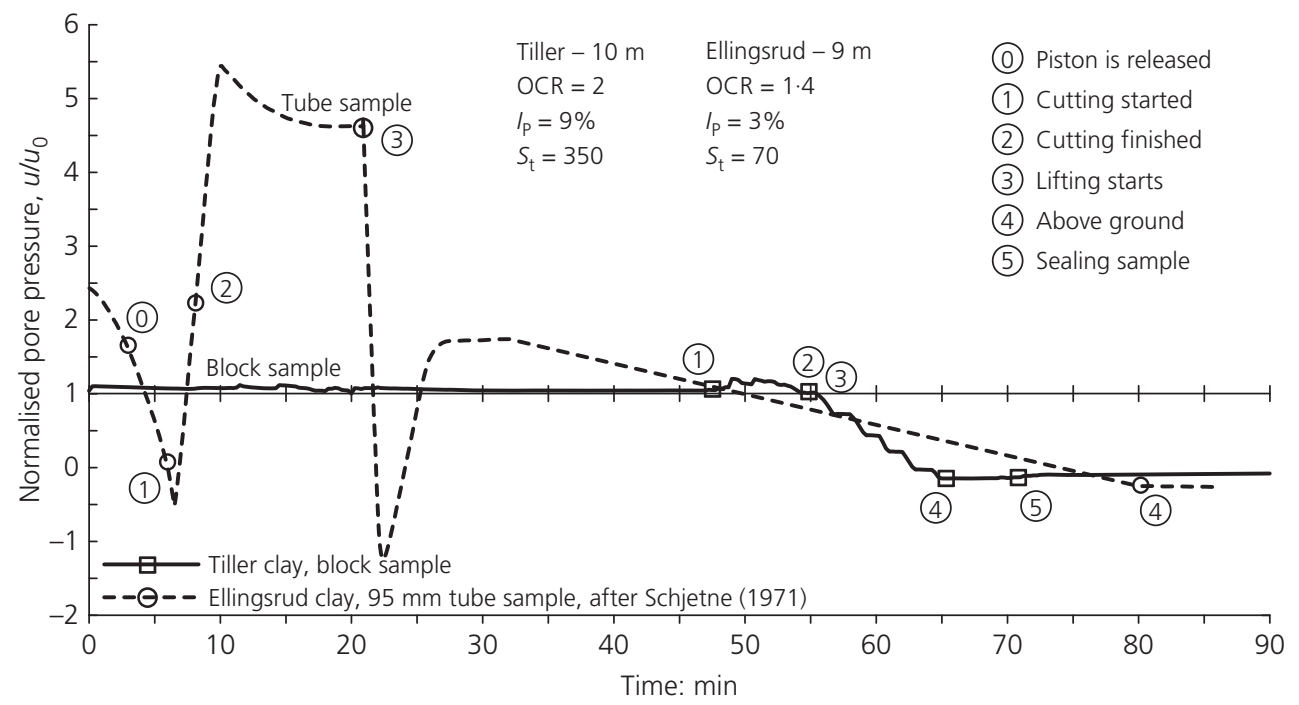

Fig. 11. Pore pressure measurements in a block sample from Tiller site compared with the measurements in a tube sample from Ellingsrud site (after Schjetne, 1971) 
very good sample quality. However, sample quality deterioration in the first hours after sampling has been demonstrated, emphasising the importance of short storage time.

From this study, the following remarks may be made.

- Reduction of the RES begins to take place less than 10 min after sampling.

- Sealing of the block sample is important to prevent the sample from swelling and to maintain its RES.

- The reduction of the RES and swelling may yield poorer quality samples. Therefore, testing of the sample should be conducted as soon as possible.

In this work, a preliminary attempt was made to study pore pressure changes during and after sampling. To give a robust recommendation of RES after sampling, more in-situ testing should be done on various materials and stress conditions.

\section{ACKNOWLEDGEMENTS}

Engineers G. Winther, E. Husby, P. Østensen, F. Stæhli, T. Westrum, K. I. Kvisvik and E. Andersen at the NTNU Geotechnical Division are acknowledged for their skills and knowledge that made the experimental work possible. The authors also extend their thanks to Multiconsult AS and NGI for their help. Master students at NTNU, H. Dang and H. Tovslid are acknowledged for some of the laboratory testing. The authors thank Dr S. Degago from Norwegian Public Road Administration for his comments on the paper. The authors also acknowledge support from the inter-governmental research program Natural hazards: Infrastructure, Floods and Slides (NIFS, 2012-2015). This work was supported by the Research Council of Norway, grant no. 246629.

\section{REFERENCES}

Adams, J. I. \& Radhakrishna, H. S. (1971). Loss of strength due to sampling in a glacial lake deposit. In Sampling of soil and rock, ASTM STP 483, pp. 109-120.

Amundsen, H. A., Emdal, A., Sandven, R. \& Thakur, V. (2015a). On engineering characterisation of a low plastic sensitive soft clay. In GeoQuébec2015 - challenges from North to South, Québec, Canada.

Amundsen, H. A., Thakur, V. \& Emdal, A. (2015b). Comparison of two sample quality assessment methods applied to oedometer test results. In Proceedings of 6th ISDCG, advances in soil mechanics and geotechnical engineering, vol. 6, pp. 923-930.

Amundsen, H. A., Emdal, A. J. \& Thakur, V. (2016a). Engineering characterization of a leached marine clay using Sherbrooke block samples. In Proc. 5th international conference in geotechnical and geophysical site characterization, ISC5 (eds B. M. Lehane, H. E. Acosta-Martinez and R. Kelly), vol. 1, pp. 529-534. AGS.

Amundsen, H. A., Thakur, V. \& Emdal, A. (2016b). Sample disturbances in block samples of low plastic soft clays. In Proceedings of the 17th Nordic geotechnical meeting, Reykjavik, Iceland, pp. 159-168.

Arman, A. \& McManis, K. L. (1976). Effect of storage and extrusion on sample properties. In Soil specimen preparation for laboratory testing, ASTM STP 599, pp. 66-87.

Atkinson, J. H., Allman, M. A. \& Bese, R. J. (1992). Influence of laboratory sample preparation procedures on the strength and stiffness of intact Bothkennar soil recovered using the Laval sampler. Géotechnique 42, No. 2, 349-354, http://dx.doi.org/ 10.1680/geot.1992.42.2.349

Baligh, M. (1985). Strain path method. J. Geotech. Engng 111, No. 9, 1108-1136.

Baligh, M., Azzouz, A. \& Chin, C. (1987). Disturbances due to ideal tube sampling. J. Geotech. Engng 113, No. 7, 739-757.

Berre, T., Schjetne, K. \& Sollie, S. (1969). Sampling disturbance of soft marine clays. In Proceedings of the 7th ICSMFE, Mexico, vol. 1, Special Session, pp. 21-24.
Bjerrum, L. (1973). Problems of soil mechanics and construction on soft clays. State-of-the-art report. In Proceedings of the 8th ICSMFE, Moscow, vol. 3, pp. 111-159.

Bozozuk, M. (1971). Effect of sampling, size, and storage on test results for marine clay. In Sampling of soil and rock, ASTM STP 483, pp. 121-131.

Brooker, E. W. \& Ireland, H. O. (1965). Earth pressures at rest related to stress history. Can. Geotech. J. 2, No. 1, $1-15$.

Carrubba, P. (2000). Stress relief disturbance and residual pore pressure in cohesive soils. Soils Found. 40, No. 1, 57-72.

Clayton, C. R. I. (1986). Sample disturbance and BS 5930. Geol. Soc. Lond. Engng Geol. Spec. Publ. 2, No. 1, 33-40.

DeGroot, D. J., Poirier, S. E. \& Landon, M. M. (2005). Sample disturbance - soft clays. Stud. Geotech. Mech. 27, No. 3-4, 91-105.

Donohue, S. \& Long, M. (2009). Suction measurements as indicators of sample quality in soft clay. Geotech. Test. J. 32, No. 3, 101416.

Donohue, S. \& Long, M. (2010). Assessment of sample quality in soft clay using shear wave velocity and suction measurements. Géotechnique 60, No. 11, 883-889, http://dx.doi.org/10.1680/ geot.8.T.007.3741.

Emdal, A., Gylland, A., Amundsen, H. A., Ksin, K. \& Long, M. (2016). Mini-block sampler. Can. Geotech. J. 53, No. 8, $1235-1245$.

Fredlund, D. G., Rahardjo, H. \& Fredlund, M. D. (2012). Nature and phase properties of unsaturated soil. In Unsaturated soil mechanics in engineering practice, pp. 29-79. John Wiley and Sons, Inc.

Gens, A. (1982). Stress-strain and strength characteristics of a low plasticity clay. $\mathrm{PhD}$ thesis, University of London.

Graham, J. \& Lau, S. L. K. (1988). Influence of stress-release disturbance, storage, and reconsolidation procedures on the shear behaviour of reconstituted underwater clay. Géotechnique 38, No. 2, 279-300, http://dx.doi.org/10.1680/ geot.1988.38.2.279.

Graham, J., Kwok, C. K. \& Ambrosie, R. W. (1987). Stress release, undrained storage, and reconsolidation in simulated underwater clay. Can. Geotech. J. 24, No. 2, 279-288.

Gylland, A., Long, M., Emdal, A. \& Sandven, R. (2013). Characterisation and engineering properties of tiller clay. Engng Geol. 164, 86-100.

Helle, T. E., Bryntesen, R. N., Amundsen, H. A., Emdal, A., Nordal, S. \& Aagaard, P. (2015). Laboratory setup to evaluate the improvement of geotechnical properties from potassium chloride saturation of a quick clay from Dragvoll, Norway. In GeoQuébec2015 - challenges from North to South, Québec, Canada.

Hight, D. W. \& Burland, J. B. (1990). Review of soil sampling and laboratory testing for the science and engineering research council, Technical report. SERC.

Hight, D. W. \& Leroueil, S. (2003). Characterisation of soils for engineering purposes. In Characterisation and engineering properties of natural soils (eds T. S. Tan, K. K. Phoon, D. W. Hight and S. Leroueil), vol. 1, pp. 255-362. Rotterdam, the Netherlands: Balkema.

Hight, D. W., Bese, R., Butcher, A. P., Clayton, C. R. I. \& Smith, P. R. (1992a). Disturbance of the Bothkennar clay prior to laboratory testing. Géotechnique 42, No. 2, 199-217, http:// dx.doi.org/10.1680/geot.1992.42.2.199.

Hight, D. W., Bond, A. J. \& Legge, J. D. (1992b). Characterization of the bothkennaar clay: an overview. Géotechnique 42, No. 2, 303-347, http://dx.doi.org/10.1680/geot.1992.42.2.303.

Hvorslev, M. J. (1949). Subsurface exploration and sampling of soils for civil engineering purposes. Report on soil sampling. Vicksburg, MS, USA: US Waterways Experiment Station.

Kallstenius, T. (1971). Secondary mechanical disturbance effects in cohesive soil samples. In Proceedings in speciality session on quality in soil sampling, 4th Asian ISSMFE, Bangkok, pp. 30-39.

Karlsrud, K. \& Hernandez-Martinez, F. G. (2013). Strength and deformation properties of norwegian clays from laboratory tests on high-quality block samples. Can. Geotech. J. 50, No. 12, $1273-1293$. 
Karlsrud, K., Otter, R. \& Gjelsvik, V. (2013). State-of-the-art: block samples (in Norwegian). In Naturfareprosjektet: Delprosjekt 6 Kvikkleire, NIFS Report no. 41/2013, p. 93.

Kirkpatrick, W. M. \& Khan, A. J. (1984). The reaction of clays to sampling stress relief. Géotechnique 34, No. 1, 29-42, http:/ dx.doi.org/10.1680/geot.1984.34.1.29.

Lacasse, S., Berre, T. \& Lefevbre, G. (1985). Block sampling of sensitive clays. In Proceedings of the 11th ICSMGE, San Francisco, vol. 2, pp. 887-892.

Ladd, C. C. \& Lambe, T. W. (1963). The strength of undisturbed clay determined from undrained tests. In Symposium on laboratory shear testing of soils, ASTM STP 361, pp. 342-371.

La Rochelle, P., Sarrailh, J., Roy, M. \& Tavenas, F. A. (1976). Effect of storage and reconsolidation on the properties of champlain clays. In Soil specimen preparation for laboratory testing, ASTM STP 599, pp. 126-146. ASTM.

La Rochelle, P., Sarrailh, J., Tavenas, F., Roy, M. \& Leroueil, S. (1981). Causes of sampling disturbance and design of a new sampler for sensitive soils. Can. Geotech. J. 18, No. 1, 52-66.

La Rochelle, P., Leroueil, S. \& Tavenas, F. (1986). A technique for long-term storage of clay samples. Can. Geotech. J. 23, No. 4 , 602-605.

Lefebvre, G. \& Poulin, C. (1979). A new method of sampling in sensitive clay. Can. Geotech. J. 16, No. 1, 226-233.

Lessard, G. \& Mitchell, J. K. (1985). The causes and effects of aging in quick clays. Can. Geotech. J. 22, No. 3, 335-346.

Lunne, T., Berre, T. \& Strandvik, S. (1997a). Sample disturbance effects in soft low plastic Norwegian clay. In Proceedings of the symposium on recent development in soil and pavement mechanics, Rio de Janeiro, Brazil, pp. 81-102.

Lunne, T., Robertson, P. K. \& Powell, J. J. M. (1997b). Cone penetration testing in geotechnical practice. London, UK: Spon Press.

NIFS (Naturfare - Infrastruktur, Flom og Skred) (2012-2015). http://www.naturfare.no.
Noorany, I. \& Seed, H. B. (1965). In-situ strength characteristics of soft clays. J. Soil Mech. Found. Div. 91, No. 2, 49-80.

Poirier, S., DeGroot, D. \& Sheahan, T. (2005). Measurement of suction in a marine clay as an indicator of sample disturbance. In Site characterization and modeling, pp. 1-10. ASCE.

Sandven, R. (1990). Strength and deformation properties of fine grained soils obtained from piezocone tests. PhD thesis, $\mathrm{NTH}$ (now NTNU).

Sandven, R., Ørbech, T. \& Lunne, T. (2004). Sample disturbance in highly sensitive clay. In ISC'2, Porto, Portugal, vol. 2, pp. $1861-1868$

Schjetne, K. (1971). The measurement of pore pressure during sampling. In Proceedings of the 4th regional Asian conference, pp. 12-16. Bangkok: ISSMFE.

Skempton, A. W. \& Sowa, V. A. (1963). The behaviour of saturated clays during sampling and testing. Géotechnique 13, No. 4, 269-290, http://dx.doi.org/10.1680/geot.1963.13.4.269.

Tanaka, H. (2000). Sample quality of cohesive soils: lessons from three sites, ariake, bothkennar and drammen. Soils Found. 20 No. 4, 57-74.

Tanaka, H. \& Tanaka, M. (2006). Main factors governing residual effective stress for cohesive soils sampled by tube sampling. Soils Found. 46, No. 2, 209-219.

Tanaka, H., Sharma, P., Tsuchida, T. \& Tanaka, M. (1996). Comparative study on sample quality using several types of samplers. Soils Found. 36, No. 1, 57-68.

Tanaka, H., Tanaka, M. \& Shiwakoti, D. R. (2001). Characteristics of soils with low plasticity: intermediate soil from Ishinomaki, Japan, and lean clay from Drammen Norway. Soils Found. 41 No. 1, 83-96.

Terzaghi, K., Peck, R. B. \& Mesri, G. (1996). Soil mechanics in engineering practice, $3 \mathrm{rd}$ edn. Wiley.

Torrance, J. K. (1976). Pore water extraction and the effect of sample storage on the pore water chemistry of leda clay. In Soil specimen preparation for laboratory testing, ASTM STP 599, pp. 126-146. 